\title{
Leadership in Higher Education - coping with AI and the turbulence of our times
}

\author{
Mariana NICOLAE \\ The Bucharest University of Economic Studies, Bucharest, Romania \\ mariana.nicolae@rei.ase.ro \\ Elena E. NICOLAE \\ The Bucharest University of Economic Studies, Bucharest, Romania \\ elena.nicolae@rei.ase.ro
}

\begin{abstract}
Today's world is clearly fractured whether we are looking at it through economic, political, cultural or educational lenses. This is in no way something new. The world has always been in this state, but the speed with which it reacted to real or perceived threats and tried to change accordingly was barely perceivable and, therefore, easier to adopt and adapt to. Today those changes happen with incredible speed and our reactions to them may not be informed or educated and are usually taken by leaders who are, at best, controversial and at worst obviously partial to their own, petty interests against the greater public good they vowed to serve. What can higher education do in such a world? Artificial intelligence (AI) is making huge progress and, although education at all levels is lagging behind in meaningfully adopting AI and working with it, the educational system is expected to react to a world divided by the fear of AI using big data, claiming jobs, and ushering in the era of loss of human supremacy or by the glorification of AI which is only a tool, fast developing indeed, but permanently controlled by human intelligence. Even if that human intelligence is concentrated into fewer and fewer human decision makers thus contributing to the already huge gap of inequality existing in today's world. The present paper will explore issues related to the way in which the leadership of higher education chooses to handle today's challenges and will use the home university of the authors to illustrate what happens in Romanian universities. The discussion will be informed by the authors' own experience in the higher education system as well as by an analysis of various discourses and narratives belonging to different stakeholders, discussing those issues in various inter/national media. The paper will offer some recommendations.
\end{abstract}

Keywords: higher education, artificial intelligence, job markets, gender, academic leadership, professional competence, university performance

\section{Introduction}

Today's world is clearly fractured whether we are looking at it through economic, political, cultural or educational lenses. This is in no way something new. The world has always been in this state, but the speed with which it reacted to real or perceived threats and tried to change accordingly was barely perceivable and, therefore, easier to adopt and adapt to. Today those changes happen with incredible speed and our reactions to them may not be as informed or as educated as would be necessary and are usually taken by leaders who are, at best, controversial and at worst obviously partial to their own, petty interests against the greater public good they vowed to serve.

We are usually not fully aware of the pace of change. How fast is fast today? We have always considered change as happening very fast. And yet pundits remind us that mentalities have changed, in spite of popular wisdom, extremely fast in less than a decade. Futurist David Houle (2015) of the US gives as an example the fact that in 2003 in the US 
Massachusetts was the only state that permitted gay marriage while the three presidential candidates from 2008, Barack Obama, Hillary Clinton and John McCain were against samesex marriage. In 2018, only ten years after, all three of them are for it and moreover it has become legal through a ruling of the Supreme Court of the US. Also, in 2017 Houle makes the forecast that we have left the knowledge economy and entered the learning economy which is a very powerful forecast for all those in the learning business, including universities.

Probably one of the most significant discussions about the complexity of today's world is Ian Goldin and Mike Mariathasan's (2015) who argue that the entire world has been transformed into one complex system by globalisation and continuously increased interconnectedness, regional changes and sustainable approach (Miron et al., 2010). Such a complex world has become extremely vulnerable to the well-known "butterfly effect" which the authors transform into the "butterfly defect" to explain "how the butterfly of change has lost its innocence and globalization has produced structural defects that propagate new forms of risk. That is related to new thinking patterns and a good understanding of nonlinearity and uncertainty (Bratianu, 2007, 2009). Societies ignore systemic risk at our peril." Another part of this increased complexity is the rise of new powers in the world as the global companies and megacities [two decades ago relatively few large cities drove economic growth while at present megacities account for $80 \%$ of the world's GDP-Howell (2018)] turn into fragile the balance of power between them and the nation-states and have led to the revival of protectionism, nationalism and xenophobia which disrupt global and human race solidarity [Harari (2016) pp 459-462, Howell (2018)]. If complexity is at the root of a fractured world, then what can leaders do to change this? Howell (2018), managing director and head of Global Programming at the World Economic Forum in Geneva offers some answers which we are going to present in Section 3 of our paper.

Academics themselves have researched these areas, the speed of change, the strategic management of change (Bratianu and Bolisani, 2015) and the various types of effects change has or might have on human society, but they are more cautious in putting forward forecasts. Hadad (2017a) analyses the characteristics of the knowledge economy in order to identify strategies of developing the knowledge economy in Romania [Hadad (2017b)]. Her conclusions are that due to a variety of reasons and situations, the knowledge economy in Romania is still more a theoretical discussion than a reality and business practice, though it would benefit universities, research institutes and other educational and research organizations which function as knowledge diffusers and transmitters and, obviously, businesses. Also, understanding knowledge dynamics constitutes a real challenge for leadership development (Bratianu, 2010).

Practitioners, that is businesses and decision makers in and for business, have their own discussions and scenarios to be able to make sense of a world that is so difficult to assess. In Davos, Switzerland, the business and political elites have come together since 1971 to discuss the major world issues of their days and to brainstorm and analyse solutions to address those issues [WEF, (2010)]. In February 2018 the same elites, though some different as individuals, came together to explore again the future of jobs: as jobs, or rather work, are a matter of a particular relevance to everybody from top to bottom, from poor to rich. PwC (2018) offers a report which aims at understanding the world of work by looking at the impact of megatrends and automation meant to help governments, organisations and/or individuals to be better prepared for a future that no one can really

DOI: 10.2478/picbe-2018-0061, pp. 683-694, ISSN 2558-9652| Proceedings of the $12^{\text {th }}$ International Conference on Business Excellence 2018 
predict. Based on research that spans over more than a decade and done by a team from PwC and the Said Business School in Oxford it surveyed 10,000 people in China, India, Germany, the UK and the US to find out how people think the workplace will evolve. The report draws four scenarios called 'Four Worlds of Work' for 2030. Even if the future may prove surprising and confounding the authors think it is a useful exercise as a starting point to prepare for it.

The present paper aims at exploring the role of higher education in today's world. How is artificial intelligence (AI) preparing students for the new world that is emerging at present? AI is advancing rapidly, but education at all levels seems to be lagging behind in meaningfully adopting it and working with it. We will explore in this paper issues related to the way in which the leadership of higher education handles today's challenges and we will use the home university of the authors to give some glimpses of what happens in Romanian universities. The discussion will be based on the authors' own experience in the higher education system as well as by an analysis of various discourses and narratives of various stakeholders.

\section{Literature review}

\section{Artificial intelligence and education}

AI has already become a common place subject both in popular media and academic conversations. AI and human-computer interaction (HCI) have taken turns in being considered "good" or "bad" concepts meaning in the words of Terry Winograd, a Stanford Professor Emeritus of computer science, that "these are two different dreams competing for the hearts (and pocketbooks) of those with the resources to pursue them"[Winograd, (2006)]. Winograd, (2006) considers that there's a deeper division between AI and HCI based on our different understandings of humans and the way technologies are created for the human benefits. Winograd says that there is a "rationalistic" approach which dreams of forming people as cognitive machines similar to the mechanisms which are built into computers. In other words thoughts in their essence, not details, can be expressed in symbols or what Harari (2006, pp. 97 - 99) calls algorithms. The second approach is what Winograd hesitatingly calls "design" in lack of a better term and focuses on the interactions between a person and their environment. Winograd strongly underlines that the two approaches are clearly intertwined repeating David Kelly's words "Enlightened trial and error outperforms the planning of the flawless intellect".

It is not the scope of our discussion here to explore the challenges of AI for human life and development. There are so many studies and books which deal with the subject and one of the most popular ones among top political and business decision makers is Harari's Homo Deus (2006) which raises the issue of the future of the human species under the conditions of extreme complexity that the world has reached while Homo Sapiens turned into Homo Deus worships the new religion that is called dataism (pp.458-462). His ideas have such an impact that at the 2018 World Economic Forum Harari was invited to address the audience in the main Congress Hall after Angela Merkel's speech and before Emmanuel Macron's in which he raised the dramatic question of whether the future will be human (Harari, 2018).

This huge shift caused by the advance of AI translates into powerful challenges over the job market and the education system. Jack Ma, founder of China's e-commerce giant the Alibaba Group, considers that the way teaching is done today has to be changed. He predicts that in about 30 years from the present moment, education as we know it today will not be able to cope with the demands of society. Knowledge-based education which was appropriate for the industrial period would no longer be serving the needs of the young who would never be able to compete with machines. Jack Ma considers that what

DOI: $10.2478 /$ picbe-2018-0061, pp. 683-694, ISSN 2558-9652| Proceedings of the $12^{\text {th }}$ International Conference on Business

Excellence 2018 
children and students should be taught are "soft skills" such as independent thinking, values and team-work.

The same points have been raised by Minouche Shafik, director of the London School of Economics, a distinguished academic and administrator, who stressed the importance of "the soft, creative skills. Research skills, the ability to find information, synthesise it, make something of it."

There is already a large and growing academic literature about AI (Artificial Intelligence Journal, for example published by Elsevier since 1970, https://www.journals.elsevier.com/artificial-intelligence) and its promises or dangers in almost every sphere of activity it touches: in business, education, health-care or agriculture, among others, but also in the military and security where the dangers of autonomous weapons or face recognition raise incredible concerns for specialists and nightmares for laypeople. And all this further raises questions related to the ethics of the whole process: since AI is only a tool, fast developing indeed, and hopefully permanently controlled by human intelligence, and since that human intelligence is concentrated into fewer and fewer human decision makers how is the world going to cope with the already huge gap of inequality existing in today's world? Illah R. Nourbakhsh (2013), a professor of robotics at Carnegie Mellon university, highlights this idea by underlining that the creators of robots, in general of technology and of AI software have the strong obligation to think ethically. And he asks an important question that is resonant with the relatively new field of academic study happiness economics: what is the role of new technologies in today's world? Is it to replace human workers and increase profits or is it to facilitate human productivity and lead to happiness? Still on the platform of the World Economic Forum, Stephane Kasriel, co-chair of the WEF's Global Future Council on Education, Gender and Work, discusses "6 ways to make sure AI creates jobs for all and not the few" which we find very important mainly because they involve the challenges of the type of education we want to have for the future and the need for the leadership that will help us to do it in Romania and elsewhere. Kasriel (2017) rightly considers that there are six principles that need to be considered when imagining how the world of work will evolve:

1. massive disruptions during the fourth industrial revolution which is unfolding [steam power (the first), electric power (the second) and digitization (the third)],

2. replacement of repetitive tasks by AI.

3. middle-skilled jobs will be most affected.

4. opportunities will be unequally distributed - in time new jobs will be created as Acemoğlu and Restrepo (2017) demonstrate using economic evidence.

5. technology designers have responsibilities and the obligation to think ethically.

6. the long-term trend can be made positive if human society chooses to make it so

It is clear that education and leadership are strongly built in all the above principles and human society needs to commit itself to responsibility and ethical choices that will allow AI to create opportunities for all, not only for a selected few.

Education is itself going through heavy re-evaluation and controversies as regards its goals and mission and its overall value to society and individuals. Evaluation of education systems has always been difficult and the criteria used in the process are under heavy and constant scrutiny. OECD, through its Directorate for Education and Skills, has developed and analysed a set of quantitative, internationally comparable indicators that it publishes annually in Education at a Glance. OECD $(2017$, p. 13) claims to offer a range of

DOI: $10.2478 /$ picbe-2018-0061, pp. 683-694, ISSN 2558-9652| Proceedings of the $12^{\text {th }}$ International Conference on Business Excellence 2018 
comparable, up-to-date indicators that reflect "consensus among professionals on how to measure the current state of education internationally" which can be used by governments in their attempts to build more effective and equitable education systems. The study provides "information on the human and financial resources invested in education, how education and learning systems operate and evolve, and the returns to investments in education". Some of the findings of this huge research involving such a sophisticated processing of big data that the study has a Reader's Guide, point out that although graduates from science-related fields are the most employable this does not happen everywhere; in general adults are better educated today, but there are obvious exceptions (see Figure 1); and, very relevant, to our discussion in this paper the total spending on tertiary education has outpaced student enrolments (Figure 2) which happens in Romania as well and the teaching profession worldwide, and particularly in Romania, suffers from lagging salaries and an ageing and gender asymmetric workforce [OECD (2017) pp 23-26].

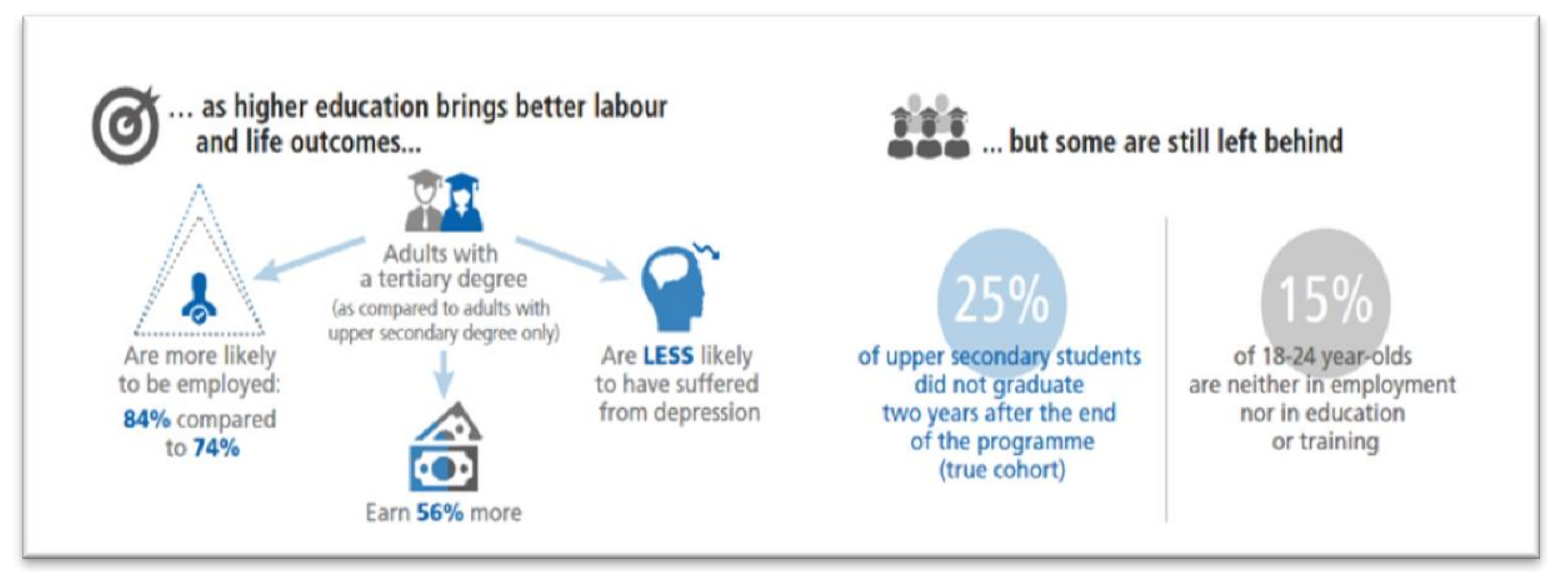

Figure 1. More adults get higher education for its perceived benefits, however there still are people who miss out.

Source: OECD (2017), p. 25.

Figure 1 above acknowledges again the importance of higher education drawing however the attention on the fact that the correlation between education and employment is not linear. A higher education degree may help the holder to get employment by $10 \%$ compared with those without a degree which is not really significant and may not justify the considerable financial and personal efforts necessary to get a degree [OECD (2017, p 23)]. However, the study shows that once a person is employed s/he will earn $56 \%$ more on average than adults who only completed upper secondary education. And the benefits continue at the level of wellbeing of an individual: it seems that people with a higher education degree are less likely to develop depression than the less-educated ones. In a period when more and more voices proclaim that higher education is in deep crisis the OECD study shifts the benefits of higher education from the purely economic and material to immaterial and difficult to quantify ones such as self-awareness and personal fulfilment. In the words of the OECD Secretary-General Angel Gurría: "Tertiary education promises huge rewards for individuals, but education systems need to do a better job of explaining to young people what studies offer the greatest opportunities for life. (...) Equitable and high quality education fuels personal fulfilment as well as economic growth." 
Yet total spending on educational institutions outpaced student enrolment

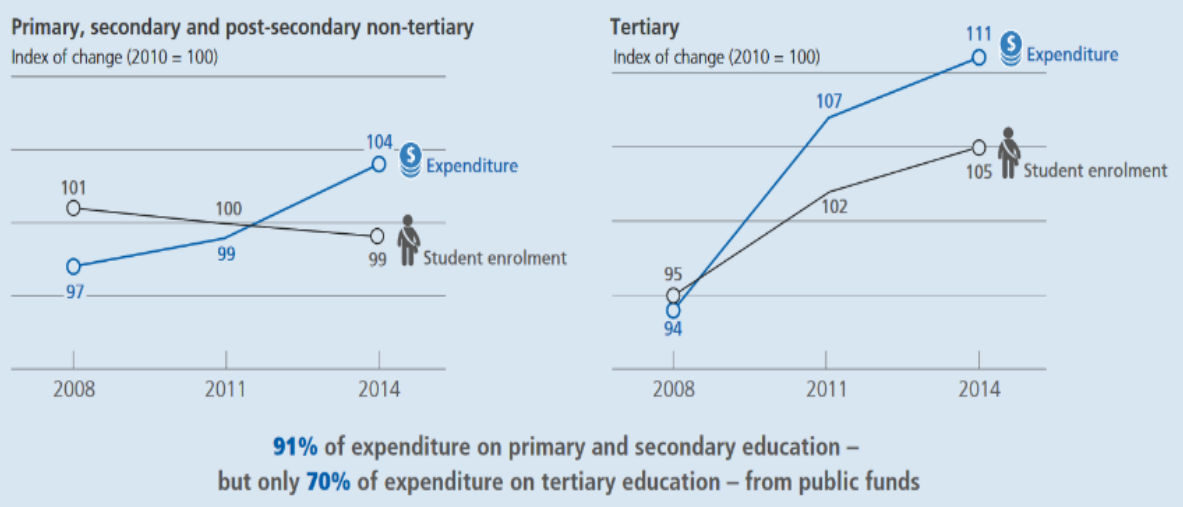

PICBE $\mid 688$

Figure 2. Students' enrolments fall behind educational spending from public funds. Source: OECD (2017), p. 25.

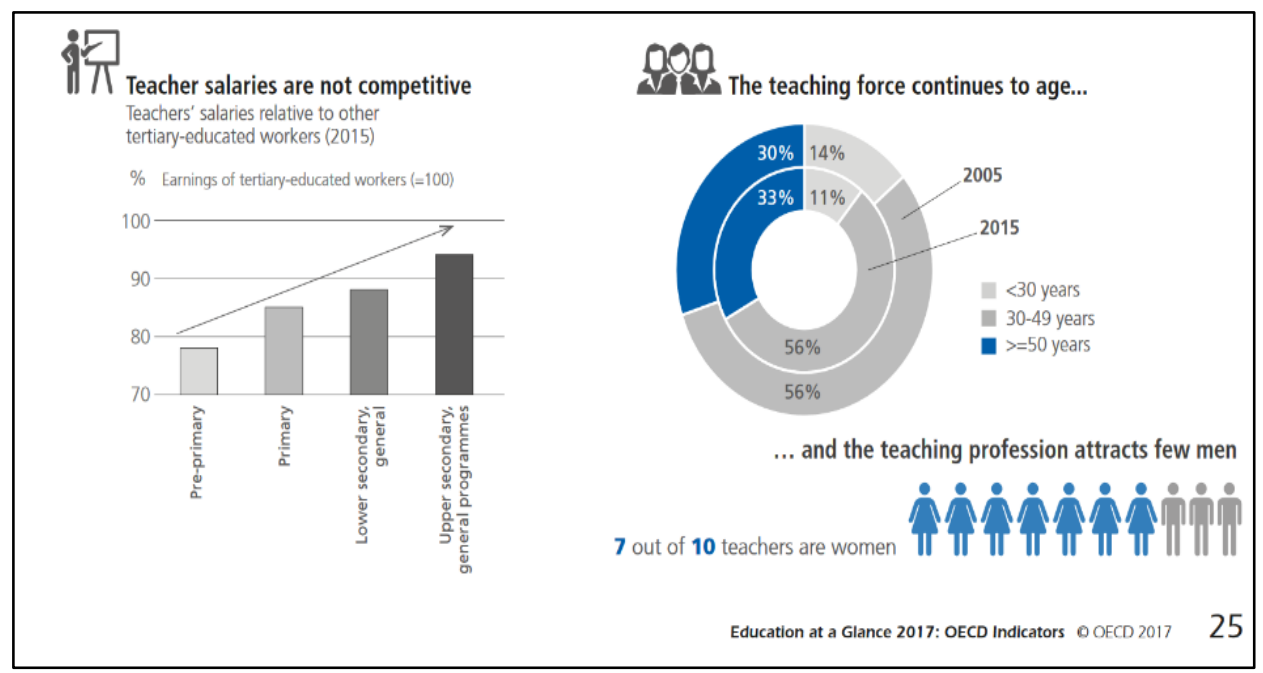

Figure 3. The teaching profession suffers from lagging salaries and an ageing and gender asymmetric workforce.

Source: OECD (2017), p. 25.

Dima and Vasilache (2016) point out several characteristics of the Romanian higher education system considered in comparison with the EU situation. As such, the authors point out that Romania is a net exporter of students who, for various reasons, migrate to more attractive study destinations in the hope of a better return on their educational investment. In an era in which internationalization is considered to be a main indicator in evaluating the higher education system of a country (Ghinea et al., 2017), Dima and Vasilache show that the number of incoming international students to Romanian universities is well below the European average correctly pointing out some causes such as: lack of awareness of the Romanian system on the international higher education market, including the EU, and its low degree of representativeness, as well as no international visibility (no Romanian universities were in top 500 in any rankings at the time of the study in 2016). In order to change this unfavourable situation, Dima and Vasilache recommend better marketing strategies and a focus on promoting at least some of the Romanian 
universities in the international top league, which in our own views (as both members in and researchers of the system), is wishful thinking as it involves not only improved financial empowerment for education in general, not restricted to the higher one only, but also a rethinking of the whole current approach to (higher) education in Romania [Nicolae (2015, 2016 a, b), Seitz, Nicolae (2014)].

QS World University Rankings 2018 in its section on EECA (Emerging Europe \& Central Asia) for the first time included the Bucharest University of Economic Studies on position 76. Which, according to QS researchers, means that BUES is among top $2.6 \%$ among the 2,900 regional universities in EECA. This in itself is obviously very good and shows the commitment of the university leadership to improve the visibility of the institution and to thus offer more and better opportunities both for its staff and its students. However, as we have shown in other articles [Nicolae (2016 b)] one university's efforts, however successful, are not enough in today's complex higher education system. Little is done in terms of political decision making in terms of formalized, transparent and open access training for university leaders and administrators in Romania or for those who are interested in following such a career path in order to help them cope with the challenges. There is a constant frowning in the Romanian media and academia about the many, unpredictable changes that the Romanian education system has gone through in the last two decades: the 25 ministers of education that managed the Ministry of Education in Romania between 1990 - February 2018 with an incredible number of four ministers in 2012. It is clear that ministers are politicians and they lead the system through experts and counsellors. Even so, the fact remains that in a highly politicized system of education as in Romania each minister appoints their own team of experts who need to have clear guidance and mandate as to what direction the system needs to develop. Those teams of experts and counsellors should have a strong professional competence to offer the minister relevant information when needed. Unfortunately, with very few exceptions, the formalized training and/or development of such high level experts is left rather to their own personal development [Nicolae (2016 b)]. It is not fully understood yet, that formalized training and development in management, leadership, educational management, research management, organizational culture, strategic planning and time management skills are critical components for academic managers' professional competence. Not to mention soft skills such as communication both in their own and international languages in order to fully and competently participate in the international discussions about the future of education. Without such professional competencies and without constant participation in international professional conversations there can be no empowerment for those academics working in administration to help them plan the vision for their organization's performance in an open and transparent world.

\section{Methodology}

The methodology of the present conceptual paper looks at questions related to the way in which the leadership of higher education chooses to handle today's challenges. We have used the home university of the authors to illustrate what happens in Romanian universities. Our research is based on our own experience in the higher education system as well as on an analysis of various discourses and narratives belonging to different stakeholders. We have used materials discussing those issues in various inter/national media.

DOI: $10.2478 /$ picbe-2018-0061, pp. 683-694, ISSN 2558-9652| Proceedings of the $12^{\text {th }}$ International Conference on Business Excellence 2018 


\section{Results and discussions}

\section{Leadership in education in a turbulent world?}

As we already mentioned in the Introduction, Howell (2018), attempts to offer some answers to what leadership can do in the face of the complexity of today's world. Howell identifies three principles of leadership that he considers essential in approaching the issues of complexity and those principles are: a) the ability of leaders to make the difference between a complicated and complex system; b) the need for leaders to rely on science and, therefore, scientific research, in order to examine complexity; and c) to be able "to combine the knowledge of complex systems with the practice of system leadership".

What Howell says, in fact, is that leaders have to accept and start from the premise that the world as it is today is a complex, interconnected system. Quoting Probst and Bassi (2014) he points out that complicated systems "are composed of many different interacting parts whose behaviour follows a precise logic and repeats itself in a patterned way" while complex systems, particularly social ones, are characterized by dynamics that are often beyond control, making them unpredictable. It is not the purpose of our paper to go into the details of complexity as a scientific field of study, just to underline that decision making in complex systems as the economy and education are today is not linear and may incur unpredictable risks and may result in perverse effects. Therefore, to lead today in what is more and more a fractured world with a diversity of agendas and interests needs Howell's third requirement which is the practice of system leadership that he borrowed from Nelson and Jenkins (2016). Nelson and Jenkins have demonstrated in their case study that "system leadership works by cultivating a shared vision for change, empowering widespread innovation and action, and enabling mutual accountability" (p. 5).

So what can universities do in order to offer a credible solution to the complexity of our world, in order to prepare students for a world that we cannot imagine and at the same time, fulfil their own missions and be transparent and accountable to an ever increasing range of stakeholders? Alice Gast (2018), President of the Imperial College London, considers that one of the most important issues the world faces today is the decline of trust, with negative effects at all levels of society. Gast sees the role of universities today as winning back that trust by listening to and working with the communities in which universities function. This, however, means revisiting and redefining the role a university plays in its smaller or larger community.

Rafael Reif (2018), President of the Massachusetts Institute of Technology, is concerned by the pace of change today that might be so disruptive that it could threaten individual lives as well as the stability of society itself. Echoing Harari (2016) in his view of the possible evolution of humanity, Reif reminds us that every past technological progress, though threatening, led in the long run to more jobs than it had destroyed and contributed to improved productivity and economic growth, higher living standards and life expectancy. But today the speed and direction of change are difficult to understand without focus, coordinated action and investment in research by governments. The advance of technology may be beneficial to everyone, only if relevant stakeholders in society take action immediately to reinvent the future of work.

The above positions were expressed within The Global University Leaders Forum (GULF) which offers "intellectual stewardship" to the World Economic Forum by addressing 
relevant educational, scientific and research agendas. GULF is formed by 27 presidents of top universities in the world.

What are the issues that regional universities, such as the Romanian ones, need to address? We have discussed some of the issues in Section 2 of this paper. We would also like to underline that trust as presented by Gast (2018) is an issue that Romanian universities need to address themselves [Seitz, Nicolae (2014)], with constant discussions about the social responsibilities of universities [Păunescu et al., (2017)] and their need to be visible internationally [Platis (2017)]. Romanians complain more and at all levels about the quality of the learning processes that go on in universities and one of the constant reproaches is that universities have transformed themselves into diplomas issuing mills. Plagiarism is also a constant issue in the public space and is perceived as a plague in the system of higher education. The discussion about content and skills in the BUES curricula has been often presented in Nicolae $(2014,2015,2016$ a) and Marinescu $(2016,2017)$ among others. The sad truth, however, is that little can be done in the absence of a sustainable and realistic vision for the specific mission of higher education institutions in Romania, backed by predictability of the process and, very important, by a financial mechanism that allows universities, clearly within an accountable and transparent framework, to be able to compete with efficiently on the educational market.

\section{Conclusion}

The present paper has explored issues related to artificial intelligence and education in a turbulent world concerned by, on the one hand, AI using big data, claiming jobs, and ushering in the era of loss of human supremacy and, on the other, by the optimism surrounding AI which seems to be a tool permanently controlled by human intelligence. We tried to briefly look at the way in which the leadership of higher education chooses to handle today's challenges internationally and in Romanian universities. The discussion was based on the authors' own experience in the higher education system as well as on an analysis of various discourses and narratives documented in research.

Education needs to re-evaluate its core values depending on the contexts in which it takes place. However, trust in education and the reduction of the already huge gap of inequality existing in today's world are among its priorities anywhere and everywhere in the world.

Our recommendations are: a) generating a sustainable and realistic vision for the specific mission of higher education institutions in Romania, b) keep the process of change predictable and c) develop a financial mechanism that allows universities, within an accountable and transparent framework, to use their funds in a dynamic and efficient.

\section{References}

Acemoğlu, D., Restrepo, P., (2017), "Robots and jobs: Evidence from the US", available at: https://voxeu.org/article/robots-and-jobs-evidence-us

Bratianu, C. (2007). Thinking patterns and knowledge dynamics. In Martins, B. and Remenyi, D. (Eds.). Proceedings of the $8^{\text {th }}$ European Conference on Knowledge Management, 6-7 September 2007. Consorci Escola Industrial de Barcelona, Barcelona, Spain (pp. 152-157). Reading: Academic Conferences. 
Bratianu, C. (2009). The frontier of linearity in the intellectual capital metaphor. In Stam, C. and Andriessen, D. (Eds.). Proceedings of the European Conference on Intellectual Capital (pp.97-103). Inholland University of Applied Sciences, Haarlem, The Netherlands, 28-29 April 2009. Reading: Academic Conferences and Publishing International.

Bratianu, C. (2010). A critical analysis of Nonaka's model of knowledge dynamics. In Rodrigues, S. (Ed.). Proceedings of the $2^{\text {nd }}$ European Conference on Intellectual Capital, ISCTE Lisbon University Institute, Lisbon, Portugal, 29-30 March 2010 (pp. 115-120). Reading: Academic Conferences and Publishing International.

Bratianu, C. and Bolisani, E. (2015). Knowledge strategies: an integrated approach for managing uncertainty. In Massaro, M. and Garlatti, A. (Eds.). Proceedings of the $16^{\text {th }}$ European Conference on Knowledge Management, University of Udine, Italy, 3-4 September 2015 (pp. 169-177). Reading: Academic Conferences and Publishing International.

Dima, M.A. and Vasilache, S. (2016), "Trends in the internationalization of European higher education in a convergence perspective", Management \& Marketing. Challenges for the Knowledge Society, Vol. 11, No. 2, pp. 449-457 DOI: 10.1515/mmcks2016-0008.

Gast, A, (2018), "Universities are not ivory towers. Here's the role they can play today", available at: https://www.weforum.org/agenda/2018/01/why-universities-needto-win-back-trust

Ghinea, V. M., Dima, A. M., \& Hadad, S. (2017). EXCELLENCE MODEL FOR SUSTAINABLE CONVERGENCE IN THE EU HIGHER EDUCATION. Amfiteatru Economic, 19(11), 1107-1122.

Goldin, I., Mariathasan, M., (2015), “The Butterfly Defect: How Globalization Creates Systemic Risks, and What to Do about It", Princeton University Press.

Hadad, S. (2017 a), "Knowledge economy: Characteristics and dimensions", Management Dynamics in the Knowledge Economy, Vol.5, No. 2, pp. 203-225.

Hadad, S. (2017 b), "Strategies for developing knowledge economy in Romania", Management \& Marketing, Challenges for the Knowledge Society, Vol. 12, No. 3, pp. 416-430. DOI: $10.1515 /$ mmcks-2017-0025.

Harari, Y.N., (2016), "Homo Deus, A Brief History of Tomorrow”, Vintage, Penguin Random House, UK.

Harari, Y.N., (2018), “Will the Future be Human?" available at: https://www.weforum.org/events/world-economic-forum-annual-meeting2018/sessions/will-the-future-be-human

Houle, D., (2015), "The Futurist: Sarasota and the speed of social change”, Herald-Tribune, available at: http://www.heraldtribune.com/business/20150706/the-futuristsarasota-and-the-speed-of-social-change

Houle, D., (2017), "Reality as we know it will change", Houle, available at: https://davidhoule.com/evolutionshift-blog/2017/11/09/reality-know-will-change

Howell, W.L., (2018), "3 leadership principles for a fractured world", WEF, available at: https://www.weforum.org/agenda/2018/01/three-leadership-principles-for-afractured-world/

Kasriel, S., (2017), "6 ways to make sure AI creates jobs for all and not the few" available at: https://www.weforum.org/agenda/2017/08/ways-to-ensure-ai-robots-create-jobsfor-all

DOI: 10.2478/picbe-2018-0061, pp. 683-694, ISSN 2558-9652| Proceedings of the $12^{\text {th }}$ International Conference on Business Excellence 2018 
Marinescu, R.E., (2016), "Intercultural Communication and Gender Studies for Business and Economic Academic Education in Romania", in Anthropologie/y \& Communication. Intersections. Editura Universității din București.

Marinescu, R.E., (2017), "Keep Your Balance: Work, Learn, Socialise", Synergy, vol 13, nr. 1, Ed. ASE, pp. 52-58, available at: http://www.synergy.ase.ro/issues/2017-vol13-no1/7-marinescu.pdf

Miron, D., Dima, A.M. and Vasilache, S. (2010). Models of the Intra-regional Trade Influence on Economic Sustainable Development in Romania. Amfiteatru Economic, XI (27), pp. 27-35

Nelson, J., Jenkins, B., (2016), “Tackling Global Challenges: Lessons in System Leadership from the World Economic Forum's New Vision for Agriculture Initiative", CSR Initiative at the Harvard Kennedy School, available at: https://www.hks.harvard.edu/sites/default/files/centers/mrcbg/files/NVAReport. pdf

Nicolae, E.E., Nicolae, M., (2016 b), “Personal Development, Professional Competence and University Performance - Who Does What?", in Euromentor. Studies about education, volume VII, No.4/December 2016, pp. 80 - 86, http://euromentor.ucdc.ro/EUROMENTORvo2nr42016.pdf

Nicolae, M., (2014), "Study Programmes in English in Non-Anglophone Countries. Looking at Impacts and Challenges from a Romanian Perspective", in Challenges, Performances and Tendencies in Organisation Management (Eds: Nicolescu, O., Lloyd-Reason, L.), http://www.worldscientific.com/worldscibooks/10.1142/9494

Nicolae, M., (2015), "Educație și leadership. Realități și experiențe românești”, Editura ASE, Colecția Et in Arcadia Ego, ISBN 978-606-505-836-1

Nicolae, M., (2016 a), "Leadership, education and bounded rationality//Leadership, educaţie şi raționalitate limitată", in "Philosophy \& Economics: Ethics and economic rationality//Filosofie şi Economie : Etică şi raţionalitate economică", coords.: Macoviciuc, V., Boşca, L.C., Vreja, L. O., - București: Editura ASE, pp. 342-348, ISBN 978-606-34-0074-2

Nicolae, M., Nicolae, E.E., (2015), "The quality of the educational process at university department level - a community of practice view" in Amfiteatru Economic, 17(39), available at: http://www.amfiteatrueconomic.ro/ArticolEN.aspx?CodArticol=2427

Nourbakhsh, I.R., (2013), "Robot Futures”, MIT Press.

OECD (2017), "Education at a Glance 2017: OECD Indicators", OECD Publishing, Paris. http://dx.doi.org/10.1787/eag-2017-en

Păunescu, C., Drăgan (Gilmeanu), D. and Găucă, O. (2017), "Examining obligations to society for QS Stars best ranked universities in social responsibility", Management \& Marketing. Challenges for the Knowledge Society, Vol. 12, No. 4, pp. 551-570.

Platis, M., (2017), "Role of University Rankings in the Context of Lack of Resources: National and Institutional Challenges" in World university rankings and the future of higher education IGI Global, DOI: 10.4018/978-1-5225-0819-9.

Probst, G., Bassi, A., (2014), “Tackling Complexity: A Systemic Approach for Decision Makers", Greenleaf Publishing

PwC, (2018), "Workforce of the future. The competing forces shaping 2030", https://www.pwc.com/gx/en/services/peopleorganisation/publications/workforce-of-the-future.html 
Reif, L. R., (2018), “A survival guide for The Fourth Industrial Revolution” available at: https://www.weforum.org/agenda/2018/01/the-fourth-industrial-revolution-asurvival-guide

Seitz, V., Nicolae, M., (2014), "The Role of Academic Values in Higher Education Convergence in Romania: A New Approach", in Handbook of Research Trends in European Higher Education Convergence, IGI Global, http://www.igiglobal.com/book/handbook-research-trends-european-higher/97340, DOI: 10.4018/978-1-4666-5998-8.

Winograd, T., (2006), "Shifting viewpoints: Artificial intelligence and human-computer interaction", Artificial Intelligence, 170 (18) , pp. 1256-1258, available at: https://doi.org/10.1016/j.artint.2006.10.012

World Economic Forum, (2010), "A Partner in Shaping History - The First 40 Years", available at: https://www.weforum.org/about/history

World Economic Forum, "Global Risks 2014”, 9th Edition, available at: http://reports.weforum.org/global-risks-2014/ 